\title{
ダイアグラムの認知 $(1)$
}

\author{
思考スタイルの違いがダイアグラムを用いた問題解決に及ぼす影響 \\ $\bigcirc$ 和田裕一・真家優子 \\ (東北大学大学院情報科学研究科) \\ キーワード：ダイアグラム，思考スタイル，個人差
}

\begin{abstract}
Perceiving spatial representation of diagram: I. The influence of thinking style on problem solving with diagram Yuichi WADA and Yuko MAIE
\end{abstract}

(Graduate School of Information Sciences, Tohoku Univ.)

Key Words: diagram, thinking style, individual differences

\section{目的}

空港の路線図や会社の組織図などで用いられることの多い ダイアグラムは、抽象的な視覚情報の表現であるといえる。 ダイアグラムは、そこに含まれる意味情報に適切な空間構造 を付与することで、情報伝達を円滑にし、意味情報の理解を 促進する。

Novick \& Hurley（2001)は、代表的なダイアグラムとして マトリックス、ネットワーク、ヒエラルキーの 3 種を挙げて おり、これら 3 つのダイアグラムにはそこに含まれる情報や 情報どうしの関係性において実質的な差異が存在することを 指摘している。従来の研究では、階層性や連結性といったダ イアグラムの構造的な特性の理解について検討したものが多 く(Novick, 2006; Hurley \& Novick, 2010)、学習者がこれ らの情報を利用することで、ある種の問題解決が促進される ことが示されている。これに対して、ダイアグラムを参照す る側の人間の認知特性とダイアグラムの認知の関係について は、たとえばコンピュータ専攻と文系専攻の学生ではヒエラ ルキーの捉え方に差があるといったように一部の知見は報告 されているものの（Novick, 2006)、これまでにあまり検討さ れてきていない。ダイアグラムの認知には、それを見る側の 性格や態度、嗜好といった個人差がいかなる影響を及ぼすの であろうか。そこで本研究では、思考の傾向や好みの違いを 反映する思考スタイル（Sternberg，1997）に着目し、ダイア グラムの認知と思考スタイルとの関係について検討すること を目的とした。思考スタイルは、質問紙によって評価される 個人の思考の好みや傾向を反映した分類であり、思考の機能、 形態、水準、範囲および傾向の 5 つの次元につき、2つから 4 つの下位タイプが設定されている。たとえば思考の機能につ いては、立案型、順守型、評価型の 3 タイプに分かれており、 回答者はいずれかの型に分類される。

今回の実験では、ネットワーク図を用いた経路探索やマト リックスにおける行列の対応判断などのダイアグラムを用い た問題（以下、ダイアグラム問題）を実験参加者に提示し、 回答に要した時間を計測した。次に、実験参加者に上述の思 考スタイルを測る質問紙に回答してもらい、問題解決の成績 (回答時間) と思考スタイルとの関係について分析した。

\section{方 法}

実験参加者 : 大学生 50 名。

手続き：「認知心理学」の受講生を対象に、集団で実施した。 実験参加者に、マトリックス、ネットワーク、ヒエラルキー のダイアグラム問題と統制条件としての文章題、およびダイ アグラムに対する好みや態度をたずねる質問項目が印刷され た問題冊子を配布し、実験者の合図にあわせて一問ずつ回答 するように求めた。各問題には回答のための 5 つの選択肢が 用意されており、実験参加者はできるだけ速く、正解と思わ れる選択肢の番号をクリッカー（INTERWRITECRICKET, eInstruction 社）のボタンを押すことで回答するように求め
られた。なお、回答制限時間内であればボタンの押し直しは 可能であることと、実験者の合図があるまで次の設問に進ま ないことがあわせて教示された。ダイアグラム問題の提示順 は実験参加者間でランダムとしたが、文章題は 3 つのダイア グラム問題を遂行した最期に提示した。その後、実験参加者 は104 項目からなる思考スタイル日本語版（比留間，2000） に回答するように求められた。

\section{結 果}

思考スタイルの分類： 先述の 5 つの次元に関して、そこに 含まれる下位分類のタイプの中でもっとも高い尺度得点を示 した型を、当該回答者の当該次元における思考スタイルとし て定義した。たとえば、思考の“機能”次元において立案型、 順守型、評価型のうち評価型の得点がもつとも高い回答者は、 思考の“機能”において評価型と分類された。

ダイアグラム問題の成績 : 実験参加者の回答内容と回答に要 した時間は、クリッカーから制御用 PC に送信され、オフライ ンで処理された。各ダイアグラム問題と文章題の正答率はほ ぼ $100 \%$ に近かった。各問題の回答時間の相関を求めたとこ ろ、ネットワークとヒエラルキーとの間に有意な正の相関が みられた $(r=.68)$ 。

思考スタイルと回答時間の関係: 各問題の回答時間に関して、 思考スタイルの各次元別に、思考スタイルの下位分類タイプ を要因とするノンパラメトリック検定（クラスカル・ウォリ ス検定とマン・ホイトニー検定）を行った。その結果、ネッ トワーク問題に関して “機能” 次元における思考スタイルの 主効果が有意であり $(p<.05)$ 、多重比較の結果、順守型 $(60.1$ 秒) の実験参加者は評価型 (42.9 秒)や立案型 (49.7 秒)に比べ てネットワーク問題の解答に要する時間が長くなる傾向にあ ることが示された。またヒエラルキー問題に関しても“機能” 次元における思考スタイルの主効果が有意であったが、多重 比較の結果、いずれのタイプ間にも有意差はみられなかった

(評価型 : 52.9 秒, 立案型 : 61.9 秒, 順守型 : 70.3 秒 )

\section{考 察}

思考スタイルの 5 つの次元のうちの “機能”次元において、 ネットワーク問題とヒエラルキー問題を解く際の回答時間に 思考スタイルの違いによる差異が認められた。具体的には、 順守型の回答者は評価型や立案型に比べて回答時間が遅い傾 向が認められた。文章題では思考スタイルの影響は見られな かったことから、ここでの差異は実験参加者の問題解決全般 に対する一般的な理解力や流暢性を反映したものとは考えに くく、ダイアグラムの認知における思考スタイルの差が影響 を及ぼしたものと考えられる。順守型の人は規則や公式に従 った手順を好む傾向にあるとされており、ネットワークやヒ エラルキーのダイアグラムを逐次的かつ系列的に目で追って 走査していたため、その構造を把握するのに時間を要したも のと推察される。 